\title{
Production and Consumption of Beef: Aspects of Russian Federation National Food Security
}

\section{O.I. Khairullina}

Doctor of Economics, Professor of Accounting and Finance Department of the Federal State Educational Institution of Higher Education, Perm State Agro-Technological University named after Academician D.N. Pryanishnikov, Perm, Russia

Phone.: (342) 212-47-38 (Work), Mobile +79128864463

Email: o.i.khayrullina@mail.ru

Received: $16^{\text {th }}$ May 2018, Accepted: 04 ${ }^{\text {th }}$ June 2018, Published: $30^{\text {th }}$ June $_{2018}$

\begin{abstract}
Food security is significant for any state. The availability of animal proteins is an important part of it, so the production of beef is necessary for Russian Federation. The definition of food security in Russian Federation is closely related to the self-sufficiency in food products through domestic production. A brief review of agrarian policy and the main results on it are given. Since 2010, the standard for the supply of meat and meat products has been set at $85 \%$, in fact, the value of $93 \%$ has been achieved in 2016 . However, one should note the imbalance in the structure of meat production. As compared to 1990, there was the increase of poultry meat production by 2.6 times. The volume of production of beef has negative changes. In 2017 , the share of beef declined to $16 \%$. Thus, 1.6 million tons of products were produced, which is 2.2 times less than in 1990. The number of cattle as the main quantitative factor of production increase, decreased 2.1 times. However, there is the increase of beef cattle number up to 2 million heads $(11 \%$ of the total number of cattle). The world production of beef continues to increase. However, in recent years, the share of Russia has significantly decreased in total and reached $2.45 \%$. The stagnation of production is evident in the conditions of high costs and unprofitable production. The dominance of the small-commodity sector reduces competitiveness and the increase of product output at a rapid pace. Consumption is a significant factor, which has a negative trend in Russia since 2015 and does not correspond to the indicators of food security (20 kg per person). In 2016, consumption was only $16.5 \%$ in the structure of all types of meat consumption. The reason is the purchasing power drop among Russian population. It is necessary to regulate production and consumption at the same time. The results of SWOT-analysis are offered. It is necessary to develop the cooperation in the form of public-private partnership; it is necessary to create the mechanisms for internal food aid among certain population categories.
\end{abstract}

Keywords: Beef, Production, Consumption, Food Security, State, Companies.

\section{Introduction}

The provision of population with food is a strategically important task for any state. The consumption of animal proteins is a necessary condition for healthy nutrition and is controlled in the context of food security.

The importance of this problem is evidenced by the establishment of the International Food and Agriculture Organization of the United Nations (FAO).

The surveys of case studies are presented analyzing the relations between trade and food (FAO, 2003, McCorriston et al., 2013; Thomas, 2006) $[26,33,31,36]$.

Food provision at the expense of the domestic capabilities of countries is also important. Bingxin $\mathrm{Yu}$, Lingzhi You (2013) proposed the classification of countries within the framework of food security, depending on the type of trade policy, the level of domestic production and the natural and climatic conditions [22].

However, it should be borne in mind that the specialization of production can increase the external vulnerability of countries (Diaz-Bonilla, 2015, Roberto Capone, 2014) [25,34].

Depending on the national characteristics of nutrition culture, natural-climatic, technical-technological and economic conditions, each country solves this problem in different ways.

Russia is a multicultural country, with a huge resource potential. There live about $2 \%$ of the world population lives there (146.8 million people), the share of agricultural land makes $4.6 \%$. The share of agriculture in the country GDP made $4.7 \%$ in 2016.

However, the development of agriculture is characterized not only by quantitative, but also by qualitative indicators of growth.

For example, in the past 25 years, the highest growth rates were recorded in countries with lower resource provision (China, India, Pakistan). 
N.I. Shagaida, V.Ya. Uzun (2017) note in their studies that China share in the world gross added value (GAV) of agriculture increased from $8.7 \%$ in 1990 to $30.1 \%$ in 2016, while the share of Russia decreased from $7.3 \%$ to $1.7 \%$. Meanwhile, this negative trend is also characteristic for developed countries - the US, the EU and Japan. In Russia, this decline is primarily related to the ruble devaluation [19].

The study of beef production crisis state and possible development of alternatives through reengineering and rationalization, and marketing activities were studied by Clephan M. Palmer (1996) [23].

The role of both public and market mechanisms in the production of beef is important (Ellen Goddard et al., 2016) [24].

The assessment of environmental production effects in livestock was reviewed by Koen Mondelaers et al. (2009) [30].

The socio-economic factors of meat consumption and their evaluation are given by Heather Mcllveen, Julie Buchanan (2001), Bill Winders, David Nibert (2004), Sylvain Charlebois et al. (2016) [28,21,35].

\section{Materials and Methods}

The study used the monographic method that allowed to determine the main trends in the production and consumption of beef by foreign countries and Russian Federation during a long analysis of data from 1990 to 2017.

It should be noted that food security and its definition has a number of characteristics for RF. For example, a special attention is paid to self-sufficiency through domestic production. At that, the calculation is carried out by finished products, the resources used for production remain unaccounted, including imported ones. Quantitative indicators dominate over the performance characteristics.

The following formula was used to determine selfsufficiency:

$$
\mathrm{SS}=\mathrm{PO} /(\mathrm{IC}+\mathrm{PC}+\mathrm{YL}) * 100
$$

where: SS - self-sufficiency;

PO - production output;

IC - industrial consumption;

PC - personal consumption;

YL - yield losses.

They used the balance method to calculate selfsufficiency in respect of meat and meat products.

SWOT analysis was conducted on the basis of expert review method. The study is aimed at the determination of the reasons for Russian beef production and consumption volume reduction. For this purpose, they analyzed the agricultural companies, the farmers and the households engaged in the cultivation of cattle meat, as well as the dynamics of meat consumption by population. The data of FAO,
OECD and the RF Federal Service of State Statistics were used.

\section{Results}

A brief description of the historical moments of Russian economy development.

From 1990 to 1995 , the transition to market relations was implemented. The result is the liberalization of the economy, the reduction of budgetary support for agriculture to a minimum.

From 1995 to 1999 - the stagnation of production, the reduction of acreage, livestock and poultry, technical means and labor resources. The result is the fall of agricultural organization incomes, the increase of losses and accounts payable.

From 2000 to 2005 - the adaptation of producers to new economic conditions, the concentration of land and capital in the hands of large industrial producers, the development of vertical integration among agricultural enterprises and the beginning of investment growth.

In 2006 the law "On the development of agriculture" appeared. Since 2007, state support has been carried out within the framework of the national project "AIC development", which set the vector for the restoration and the development of agriculture in Russian Federation.

From 2008 to 2012, the Program for the Development of Agriculture and the Regulation of Agricultural, Raw Material and Food Markets was implemented. The main mechanism was the subsidizing of the interest rate on loans, mostly short-term loans.

In 2010, the country approved the Food Security Doctrine, which identified the strategic priorities for food security. This mainly concerned food selfsufficiency.

From 2013 to the present, the Program for the Development of Agriculture until 2020 has been implemented.

The existing state support system has some shortcomings. In particular, there is no transparent mechanism for agricultural budget development; the dynamic nature of financing volume and the list of activities; an unequal access to support for all categories of producers.

The producers adapted to the created conditions of state support: the priority of production was shifted towards single large industrial companies for the production of agricultural products, concentrating the main volumes of budgetary funds. The products with a short technological production cycle and lower costs received an unprecedented growth. For example, this tool place in livestock - the production of poultry meat, pork and eggs. At the same time, the stagnation in cattle breeding is evident. 
The overall indicator of meat and meat product provision remains significant for food safety, according to which the standard is set $-85 \%$ at least. Let's consider the food balance of meat and meat products in Russian Federation. There is a positive dynamic in production volumes: in 2017 there was an internal growth of 1.4 times as compared to 2010, the import decreased significantly - in 2.6 times. The export of meat and meat products increased almost 3 times, personal consumption increased. Selfsufficiency reached $93 \%$, which is higher than the established standard (Table 1).

The overall review of the food balance indices indicates a steady increase of production volume by Russia

Table 1. Balance of Meat and Meat Products (RF), million tons

\begin{tabular}{|c|c|c|c|c|c|c|c|c|}
\hline \multirow[t]{2}{*}{ Indicator } & \multicolumn{8}{|c|}{ Year } \\
\hline & 2010 & 2011 & 2012 & 2013 & 2014 & 2015 & 2016 & 2017 \\
\hline \multicolumn{9}{|c|}{ Resources: } \\
\hline $\begin{array}{l}\text { Reserves at the } \\
\text { beginning of the year }\end{array}$ & 0,80 & 0,80 & 0,79 & 0,84 & 0,87 & 0,81 & 0,81 & 0,80 \\
\hline Production & 7,17 & 7,52 & 8,09 & 8,54 & 9,07 & 9,47 & 9,90 & 10,37 \\
\hline Import & 2,86 & 2,71 & 2,71 & 2,48 & 1,95 & 1,32 & 1,25 & 1,09 \\
\hline $\begin{array}{ll}\text { Total amount of } \\
\text { resources }\end{array}$ & 10,83 & 11,03 & 11,59 & 11,86 & 11,89 & 11,60 & 11,96 & 12,27 \\
\hline \multicolumn{9}{|c|}{ Use: } \\
\hline $\begin{array}{l}\text { Production } \\
\text { consumption }\end{array}$ & 0,04 & 0,04 & 0,06 & 0,05 & 0,06 & 0,06 & 0,05 & 0,04 \\
\hline Losses & 0,02 & 0,02 & 0,02 & 0,02 & 0,02 & 0,02 & 0,02 & 0,01 \\
\hline Export & 0,10 & 0,08 & 0,13 & 0,12 & 0,14 & 0,14 & 0,24 & 0,31 \\
\hline Personal consumption & 9,87 & 10,11 & 10,55 & 10,81 & 10,88 & 10,64 & 10,85 & 11,11 \\
\hline $\begin{array}{l}\text { Reserves by the end of } \\
\text { the year }\end{array}$ & 0,80 & 0,79 & 0,84 & 0,86 & 0,81 & 0,74 & 0,80 & 0,79 \\
\hline Self-sufficiency, \%* & 72,2 & 73,99 & 76,14 & 78,52 & 82,84 & 88,41 & 90,68 & 92,87 \\
\hline
\end{tabular}

Source: compiled and calculated by the author on the basis of data of RF Federal State Statistics Service (2017)

However, there is a certain imbalance in production structure. In particular, there was the increase of poultry meat production by 2.6 times as compared with 1990. This is due to high rates of funds turnover in the industry and due to investment attractiveness.
Prior to 2005, pork production declined, and since 2006 the increase takes place, which is largely conditioned by state support increase.

The volumes of beef production have negative changes throughout the study period (Figure 1).

Figure 1. The Volumes of Main Types of Meat Production in Russian Federation Source: expert-analytical center of agribusiness "AB-Center" www.ab-centre.ru.

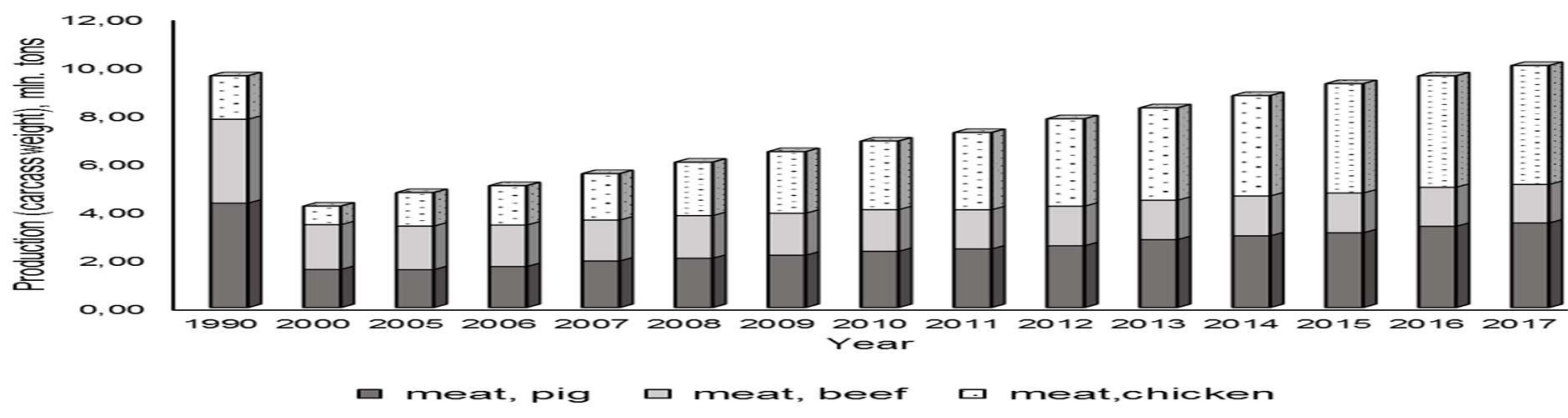


Thus, in 2017 the reduction was 2.1 times as compared with 1990. The reasons for this situation are the decrease of dairy cattle amount, which is the main source of meat in Russian Federation, and the pace of beef cattle development.

The dynamic changes in production have also affected its structure. For example, in 1990, the largest share was represented by pork (45\%) and beef (36\%).

Since 2004, the share of beef has decreased to $29 \%$, and since 2017 this indicator has been at the level of $16 \%$. Thus, 1.6 million tons of products were produced, which is 2.2 times less than in 1990.

Thus, at the present stage the increase of poultry meat production is at a higher rate as compared to the rest ones and it led to the dominance of this product in the structure - $49 \%$.

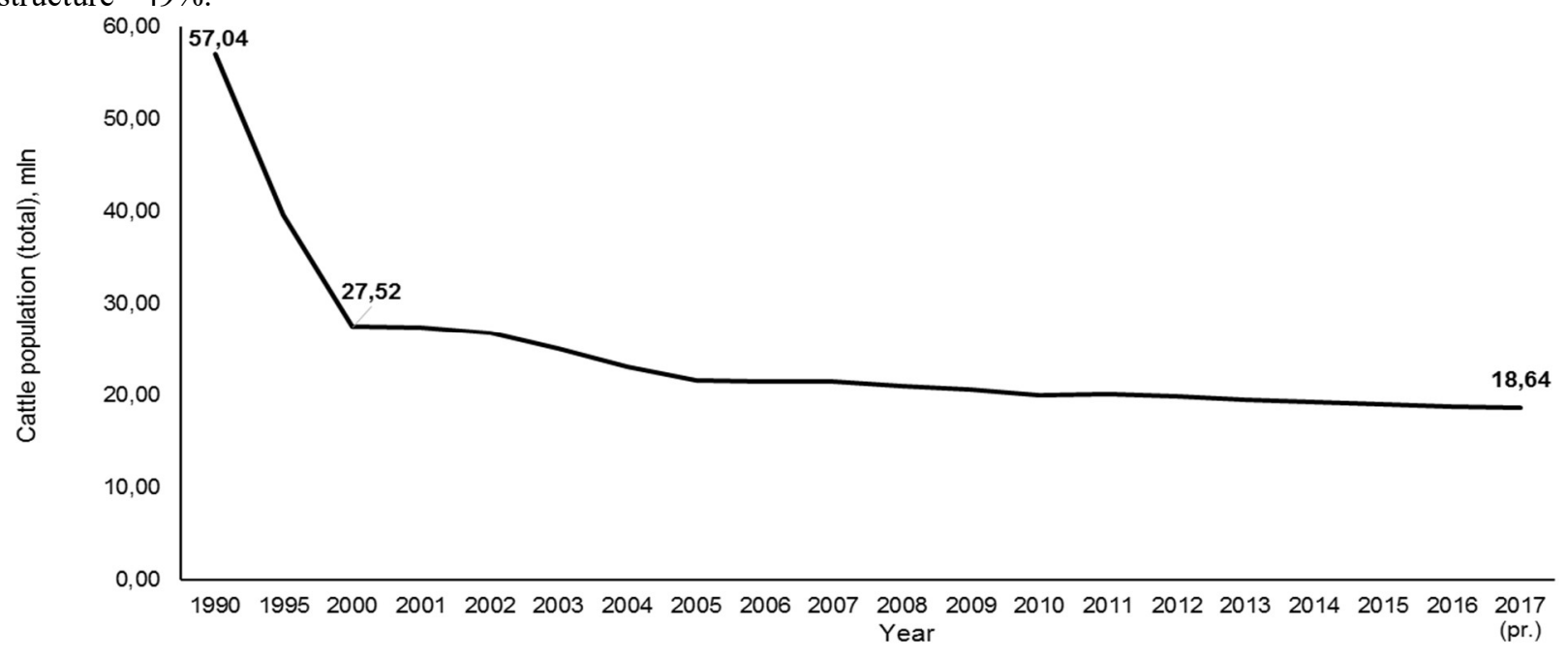

Figure 2. The amount of livestock in Russia
Let us turn to the world trends. In 2016, the total volume of beef production amounted to more than 65 million tons. The absolute leaders are the United States (17.39\% or 11.47 million tonnes), Brazil (14.07\% or 9.28 million tonnes) and China $(10.63 \%$ or 7.01 million tonnes).

FAO forecast shows that by 2026 the growth in the developing countries will be $16 \%$ (FAO, 2017, OECD, 2017) [33].

There was the decrease of the share in world production for Russia from 5\% in 1995 to $2.5 \%$ in 2016.

As we noted, one of the main factors determining the volume of production is the livestock amount (Figure 2).

\section{Source: compiled and calculated by the author on the basis of RF Federal State Statistics Service data (2017)}

Figure 2 shows the decline in the number of livestock from 1990 to 2017 by more than 3 times.

According to the RF Ministry of Agriculture, the stock of meat specialized cattle is 2 million heads $(11 \%$ of the total number) and it continues to grow. Mainly the cattle of meat breeds are concentrated in the following federal districts: Southern - 22\%, Central - 19\% and Volga region - 14\%.

It is impossible to solve the problem of Russian population provision with beef solely at the expense of specialized meat cattle breeding in a short term. It is necessary to recognize the necessity of this product obtaining by the increase of dairy cattle and combined breed number (Khairullina, 2017) [15].

The institutional agrarian structure of production in RF has its own peculiarities. Agriculture is represented by three categories: agricultural companies, farms and households. During the period under study their contribution to the total volume of beef production varied depending on created economic conditions and state policy.

In 1990, the number of cattle was concentrated in agricultural companies - 83\%. In 1995, 70\% remained in agricultural companies, the share of households increased to $29 \%$, farmers concentrated only $1.5 \%$ of the population.

The modern structure has also undergone changes. In 2017, the share of agricultural companies made $44.2 \%$, the share of households $-42.5 \%$ and the share of farmers - $13.3 \%$. This state of affairs is the consequence of small agrarian business support by the state in the form of grants for family livestock farms and the subsidizing of interest rates on loans.

It is important to note that with the beginning of the economic crisis in Russia in 1998 and the withdrawal of investors from this sector of the agrarian economy, the production of beef has become small-scale one: $52 \%$ of the output falls on households with a low degree of efficiency. 
By 2017, the share of production made by households has grown to $56 \%$, by agricultural companies - $34 \%$ and $9 \%$ was produced by farmers. The existing losses $(-26 \%)$ leave no room for further development. It is necessary to change the state policy in this direction. The current situation with the production of beef has a close connection with its consumption.
The level of rational norm achievement concerning food consumption per capita is also the indicator of RF food security. The recommended norms of consumption per person at the national level are the following ones: beef - $20 \mathrm{~kg}$, pork - $18 \mathrm{~kg}$ and poultry meat $-31 \mathrm{~kg}$. It is noteworthy that the Doctrine itself has no data on the specific structure of meat and meat products production

Let us turn to the data of average per capita annual consumption in RF (Table 2).

Table 2. Average per capita consumption of beef in RF ( $\mathrm{kg}$ per person)

\begin{tabular}{|l|c|c|c|c|c|c|c|}
\hline \multicolumn{1}{|c|}{ Type of meat } & 1990 & 1995 & 2000 & 2005 & 2010 & 2015 & 2016 \\
\hline Beef & 43,29 & 47,81 & 43,29 & 36,77 & 24,36 & 17,38 & 16,49 \\
\hline Pork & 34,80 & 32,61 & 35,99 & 31,89 & 32,88 & 32,66 & 34,29 \\
\hline Poultry & 18,01 & 15,02 & 17,52 & 28,21 & 40,16 & 47,80 & 47,05 \\
\hline Other types & 3,90 & 4,56 & 3,19 & 3,13 & 2,61 & 2,16 & 2,17 \\
\hline Total & 100 & 100 & 100 & 100 & 100 & 100 & 100 \\
\hline
\end{tabular}

Source: compiled and calculated by the author on the basis of RF Federal State Statistics Service data (2017)

The table data show serious structural changes in meat consumption by population. In 1990, the largest proportion in the diet was beef - $43.3 \%$, and in 2016 it made only $16.5 \%$, which does not meet the criteria for national food security (which should be at least $27.4 \%)$.

According to OECD data (2017), the highest per capita consumption of beef per capita was in Uruguay (43.1 $\mathrm{kg}$ ), Argentina $(38.6 \mathrm{~kg})$, Brazil $(25.7 \mathrm{~kg})$ and the United States $(25.6 \mathrm{~kg})$. Note that they are also the largest producers of this category of meat.
At the present stage, Russians prefer poultry meat. In comparison with other goods, beef is characterized by higher production costs and higher prices for products, and the real solvency of the population has declined markedly in recent years. Besides, a proper attention is not given to healthy nutrition. With the annual population growth, the proportion of people suffering from obesity increases, especially among adolescents. The share of spending on food also continues to increase. Since 2015, the purchasing power of the population for beef also declined markedly (table 3 ).

Table 3. Incomes and expenditures of RF population on average per capita

\begin{tabular}{|l|c|c|c|c|c|c|c|}
\hline \multicolumn{1}{|c|}{ Indicator } & 2011 & 2012 & 2013 & 2014 & 2015 & 2016 & $\begin{array}{c}2016 \text { by } \\
2011, \%\end{array}$ \\
\hline Average monthly income per person, rubles. & 20780 & 23221 & 25928 & 27767 & 30467 & 30744 & 147,95 \\
\hline Share of expenses, in incomes, \% & 56,38 & 56,27 & 54,59 & 54,36 & 50,20 & 54,10 & - \\
\hline $\begin{array}{l}\text { Share of expenditure on food in total } \\
\text { income, \% }\end{array}$ & 19,63 & 18,84 & 18,11 & 18,41 & 18,73 & 20,23 & - \\
\hline $\begin{array}{l}\text { Share of food expenditure in final } \\
\text { consumption expenditures, \% }\end{array}$ & 34,81 & 33,48 & 33,17 & 33,86 & 37,32 & 37,40 & - \\
\hline Buying capacity for beef, kg & 78,80 & 79,30 & 87,30 & 89,50 & 82,10 & 81,80 & 103,81 \\
\hline
\end{tabular}

Source: compiled and calculated by the author on the basis of RF Federal State Statistics Service data (2017)

The same period is characterized by a maximum price increase for this product.

According to FAO predictions (2017), the world prices for beef also continue to grow. By 2026, it is expected that beef price will increase to US \$3,984 per tonne in slaughter weight. It should be noted that now the domestic purchase price in Russian Federation is approximately $15 \%$ higher than the world reference one [33].

\section{Discussions}

The need to intensify the production of beef through the introduction of modern technologies and the cooperation of large and small beef producers is noted by H.A. Amerkhanov (2004) [1].

V. Kalashnikov et al. (2010), I.M. Dunin and et al. (2014) and S.A. Miroshnikov (2014) determined the prospects for the growth of production in modern conditions, where the key problem is the lack of an equitable distribution of income within the value creation chain. The highest yield remains in trade, and not in production $[5,4,8]$. 
The need to develop market infrastructure and partnerships throughout the value chain of beef is noted by Andrew Fearne (1998), Ellen Goddard et al. (2016) [20,24].

The next direction is the technical and the technological modernization volume increase with the participation of government support in the medium term (N.M. Morozov, 2013; I.A. Tikhomirov, 2015) $[9,11]$.

Undoubtedly, it is necessary to increase the amount of state support in the form of grants and food aid. This direction is not sufficiently developed in Russia.

The perfection of state support mechanism for agriculture is carried out by Russian scientists N.A. Borkhunov et al. (2005), I. Buzdalov (2012), E.N. Krylatyh (2013) and O.I. Khairullina $(2012,2014)$ [2, $3,6,14,15,16]$. It was revealed that public-private partnership is a promising trend (I.S. Sandu et al., 2015, V.Z. Mazloyev et al., 2016) [10,7].

The problem of budgetary funds distribution among agricultural producers is represented by currently insufficiently transparent system, large agricultural companies account for the bulk of state support (V.Ya. Uzun, 2012; IG Ushachev, 2012) [15,16].

The economic methods of import substitution state regulation in the domestic meat market are proposed by A.V. Chinarov (2015) [18].

The experience of the USA in the implementation of food aid programs is interesting. A distinctive feature is the target group (for example, pregnant women, children, the elderly), as well as the requirements for product groups (commercial products and prepared meals) (Kirsten, J. Colello, 2017; FAO, 2013) [29,27]. It is necessary to create such a system of food aid for low-income and needy citizens, which will increase the consumption of beef (Khairullina, 2017) [15].

The vertical integration between livestock producers, meat processors, wholesalers and retailers is interesting. This creates the opportunities for scale effect increase in production and distribution (Ming Juan Ding et al., 2014) [32]

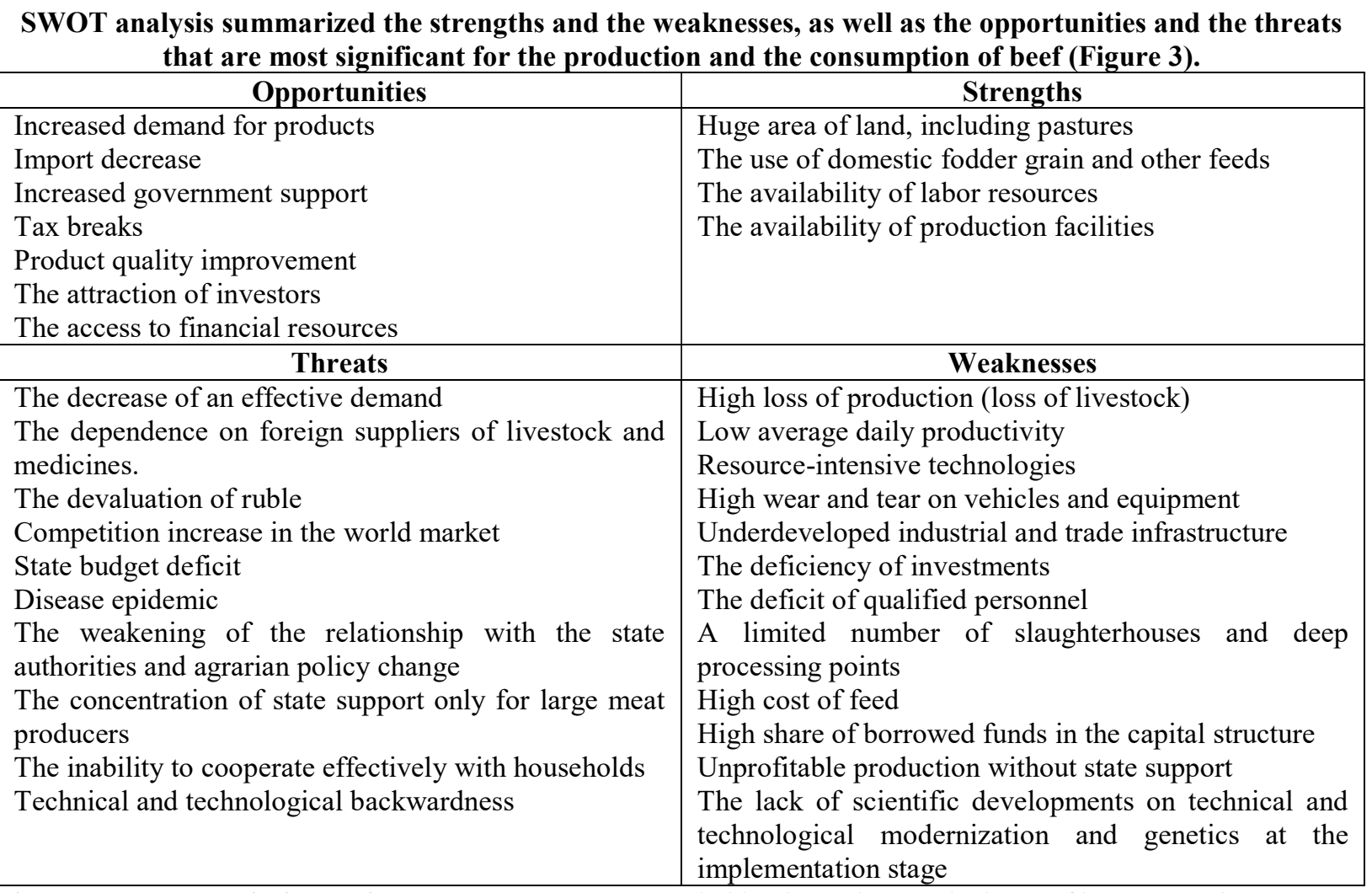

Figure 3. SWOT Analysis Matrix Source: compiled by the author on the basis of his own studies

According to the proposed matrix, they determined the key areas for this sector of the agrarian economy further development.

\section{Summary}

It is necessary to take measures by the state that would promote, on the one hand, an effective production of cattle meat and the increase in volumes, and would stimulate the consumption of beef in the framework of rational nutrition, on the other. 
The organization of an effective cooperation in the form of public-private partnership will help to solve problems.

The data presented in the matrix of SWOT analysis should be taken into account during the development of RF bills and programs in order to overcome the crisis of beef production.

\section{References}

[1] Amerkhanov, Kh.A. Meat cattle breeding in Russia and abroad [Text] / Kh.A. Amerkhanov. - M., 2004. - 304 p.

[2] Borkhunov, N.A. Reproduction and state support of agriculture / N. Borkhunov, N. Zaruk // Economics of Agriculture of Russia. - 2005. - No. 11. - pp. 28-29.

[3] Buzdalov I. On the Economic Approach to Systemic Modernization of Agriculture in Russia / I. Buzdalov // Society and Economics. - 2012. - № 3-4. - pp. 117-121.

[4] Dunin, I.M. Prospects for the development of beef cattle breeding in Russia under current conditions. I.M. Dunin, G.I. Shichkin, A.A. Kochetkov // Dairy and beef cattle-breeding 2014. - № 5. - pp. 2-5.

[5] Kalashnikov V. Meat cattle breeding: state, problems and the prospects of development / V. Kalashnikov, H. Amerkhanov, V. Levakhin // Dairy and meat cattle breeding. 2010. - No. 1. - pp. 2-5.

[6] Krylatyh E.N. State program for the development of agriculture and its relationship with the concept of agricultural food sector multifunctionality / E.N. Krylatyh // Economics of agricultural and processing enterprises. 2013. - No. 4. - pp. 12-15.

[7] Mazloev V.Z., Khairullina O.I. Publicprivate partnership for the technical modernization of beef cattle breeding // Economics of agricultural and processing enterprises. - 2016. - No. 9. - pp. 28-33.

[8] Miroshnikov S.A. The domestic market of beef: What do we know about it? / S.A. Miroshnikov // Meat Industry. - 2014. - №5. - pp. 10-12.

[9] Morozov N.M. The system of machines and machine technologies for the production of livestock products during the period until 2020 / N.M. Morozov // Bulletin of VNIIMZh. - 2013.-No.1 (9) .- pp. 74-91.

[10] Sandu I.S., Ryzhenkova N.E. The role of public-private partnership in the development of the national innovation system in the agricultural-industrial complex [Electronic resource]. - Access mode: // ukros.ru/wp-

content/uploads/2015/01/санду_рыженкова .doc

[11] Tikhomirov I.A. Technological modernization of beef production / I.A. Tikhomirov // Bulletin of VNIIMZh. - 2015. - No. 3 (19). - pp. 35-44.

[12]Uzun, V.Ya. Russian policy of agriculture support and the need for its adjustment after entry into the WTO / V. Ya. Uzun // The Issues of Economics. - 2012. - No. 10. - pp. 132-148.

[13] Ushachev I.G. The measures ensuring the competitiveness of agriculture in the context of Russia entry into the WTO / I.G. Ushachev // AIC: Economics and Management. 2012. № 9. - pp. 9-13.

[14] Khairullina O.I. State mechanism of agriculture regulation. // Accounting in agriculture. - 2014. - No. 4. - pp. 70-79.

[15] Khairullina O.I. Prospective trends of beef production and consumption state support in Russian Federation [Text] / O.I. Khairullina // AIC: Economics and Management, 2017. № 4. - pp. 68-75.

[16] Khairullina O.I. The strategy of animal husbandry state support in the Perm Krai // Agrarian Bulletin of the Urals. - 2012. - No. 6. - pp. 112-116.

[17] Khairullina O.I. State subsidies in agriculture: accounting and taxation // International accounting. - 2012. - No. 10. pp. 19-26.

[18] Chinarov A.V. Economic methods of import substitution state regulation in the domestic meat market / A.V. Chinarov, N.I. Strekozov, V.I. Chinarov // Economics of agricultural and processing enterprises. - 2015. - No. 1. pp. $2-5$.

[19] Shagaida N.I., Uzun V.Ya. The trends of development and the main challenges of the Russian agrarian sector (analytical report), 2017. $90 \mathrm{p}$. 